\title{
Kształtowanie percepcji słuchowej u dzieci dwujęzycznych jako remedium na niewłaściwą realizację szeregów: szumiącego, syczącego oraz ciszącego
}

\author{
Developing the perception of hearing in bilingual children \\ as a remedy for the improper realization of the following \\ sounds: fricatives, sibilants and alveolo-palatals
}

\author{
Monika Plata
Polski Uniwersytet na Obczyźnie w Londynie
ORCID: 0000-0001-8469-1563
}

\begin{abstract}
Sigmatism, or improper realization of the dental sounds of the alveolo-palatal consonants $\left(s^{\prime}, \dot{z}, \dot{c}, d \dot{z}\right)$ and/or sibilants $(s, z, c, d z)$ and/or fricatives $(s z, \dot{z}, c z, d \dot{z})$, is one of the most severe speech therapy problems in bilingual children attending Polish Saturdays schools. Lisping is caused, among others, by improperly built speech organs or their low efficienc, but also by disorder s ovf phonemic hearing - inappropriate reception of hearing aids. In bilingual children who speak Polish and English simultaneously, there is often an additional phonetic difficulty associated with the weak differentiation of consonants, ś, $\dot{z}, \dot{c}, d \dot{z}$ in opposition to $s z, \dot{z}, c z, d \dot{z}$. The development of phonemic hearing in young children is one of the methods to prevent lisping, in older people - a way to eliminate it. The role of teachers of Saturday schools is invaluable in this case - phonemic hearing exercises play a significant role not only in learning the correct articulation, but also in mastering the skills of reading and writing.
\end{abstract}

Key words: sigmatism, phonemic hearing, bilingualism

Streszczenie: Sygmatyzm, czyli nieprawidłowa realizacja głosek dentalizowanych szeregu ciszącego $(s, \dot{z}, \dot{c}, d \dot{z}) \mathrm{i} / \mathrm{lub}$ syczącego $(s, z, c, d z)$ i/lub szumiącego $(s z, \dot{z}, c z, d \dot{z})$, to jeden z najbardziej dotkliwych problemów logopedycznych występujących u dzieci dwujęzycznych uczęszczających do polskich szkół sobotnich. Seplenienie powodowane jest m.in. przez nieprawidłową budowę narządów artykulacyjnych bądź niską ich sprawność, ale także przez zaburzenia słuchu fonematycznego - niewłaściwą recepcję słuchową głosek. U dzieci dwujęzycznych posługujących się równolegle językiem polskim i angielskim często pojawia się dodatkowa trudność fonetyczna związana ze słabym różnicowaniem spółgłosek ś, ź, ́́, $d \dot{z}$ w opozycji do $s z, \dot{z}, c z, d \dot{z}$. Kształtowanie słuchu fonematycznego u małych dzieci jest jedną z metod pozwalających na zapobieżenie seplenieniu, u starszych - sposobem na jego eliminację. Rola nauczycieli szkół sobotnich jest w tym przypadku nieoceniona - ćwiczenia słuchu fonematycznego odgrywają niebagatelną rolę nie tylko w nauce poprawnej artykulacji, ale również w opanowaniu umiejętności czytania i pisania.

Słowa kluczowe: sygmatyzm, słuch fonematyczny, dwujęzyczność 
W analizie przygotowanej w 2015 roku przez Główny Urząd Statystyczny ${ }^{1}$ przedstawiono dane, z których wynika, że w latach 2009-2013 w Wielkiej Brytanii Polki urodziły ponad 100 tys. dzieci (w porównaniu do 38 tys. urodzeń w latach 2004-2008). Dzieci te, realizując obowiązek szkolny, obecnie znajdują się w systemie edukacji brytyjskiej, część z nich uczęszcza równolegle do szkół języków ojczystych, tzw. szkół sobotnich. Wedle szacunków Macierzy Polskiej - organizacji skupiającej placówki oświatowe zaangażowane w naukę języka polskiego oraz krzewienie polskiej kultury w Wielkiej Brytanii - obecnie w Anglii, Walii, Szkocji i Irlandii Północnej jest zarejestrowanych łącznie 130 szkół języka ojczystego, choć należy pamiętać, że nie wszystkie tego typu instytucje zabiegają o znalezienie się w oficjalnych rejestrach.

Rola nauczycieli pracujących $\mathrm{w}$ polskich szkołach sobotnich jest nieoceniona, nie tylko w obszarze profilaktycznych działań logopedycznych, ale także wspierania terapii wad wymowy w zakresie posiadanych kompetencji. Jest to istotne również ze względu na znikomą wobec potrzeb liczbę czynnych zawodowo logopedów pracujących na Wyspach.

W latach 2015-2018 prowadziłam konsultacje logopedyczne w czterech szkołach języka ojczystego na terenie Londynu, były to: ProPolonia Sobotnia Szkoła Języka Polskiego w Hounslow, Polska Szkoła Sobotnia im. Fryderyka Chopina w South Croydon, Polska Szkoła Sobotnia im. Marii Konopnickiej w Willesden Green oraz Szkolny Punkt Konsultacyjny przy Ambasadzie RP w Isleworth. W ciągu trzech lat przeprowadziłam przesiewowe badania mowy u ponad 100 dzieci w wieku od 5 do 11 roku życia, stosując test sprawdzający percepcję i wymowę dzieci wielojęzycznych (Madelska 2010), a także analizując próbki wypowiedzi spontanicznej uzyskanej w swobodnej rozmowie. Sygmatyzm był najczęściej występującym zaburzeniem artykulacji u dzieci dwu- bądź wielojęzycznych uczęszczających do polskich szkół sobotnich w Wielkiej Brytanii.

Sygmatyzm to niewłaściwa realizacja głosek dentalizowanych, tj. palatalnych (szereg ciszący: $\dot{s}, \dot{z}, \dot{c}, d \dot{z}$ ), zębowych (szereg syczący: $s, z$, $c, d z$ ) oraz dziąsłowych (szereg szumiący: $s z, \dot{z}, c z, d \dot{z}$ ). Nieprawidłowa realizacja dźwięków mowy w sygmatyzmie może obejmować jedną lub wiele głosek. Dziecko może artykułować inne głoski (np. zuk zamiast $\dot{z} u k$ ) - parasygmatyzm, pomijać głoski sprawiające trudność (np. alik zamiast szalik) - mogisygmatyzm, lub zastępować je dźwiękami zdeformowanymi - sygmatyzm właściwy.

Wymowa poszczególnych głosek nabywana jest przez dziecko stopniowo, poczynając od tych najłatwiejszych, skończywszy na najtrudniejszej i pojawiającej się najpóźniej głosce $r$, która jest najczęściej poprawnie realizowana dopiero po 6. roku życia. Należy pamiętać, że do wad wymowy nie zaliczamy niewłaściwych wymówień charakterystycznych dla mowy

${ }^{1}$ https://stat.gov.pl/files/gfx/portalinformacyjny/pl/defaultaktualnosci/5468/20/1/1/dzieci_w_polsce w 2014 roku_charakterystyka demograficzna.pdf (dostęp: 3.08.2018)

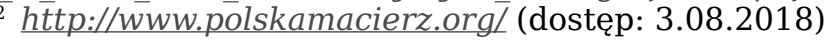


dziecięcej. Biorąc pod uwagę ów aspekt, za naturalne należy uznać np. zamienianie u 3-latka głoski $s$ na ś (śok zamiast sok), jednak po 4. roku życia wymowa taka będzie już traktowana jako wada wymowy.

W przypadku głosek dentalizowanych ich przyswajanie przebiega w następujących etapach:

- do 3. r.ż. głoski: ś, ź, ć, dź;

- do 4. r.ż. głoski: $s, z, c, d z$;

- do 5. r.ż. głoski: $s z, \dot{z}, c z, d \dot{z}$.

Substytucje głosek z wymienionych szeregów na łatwiejsze, występujące w systemie języka polskiego, mają prawo występować u dzieci między 3 a 5 rokiem życia (w zależności od szeregu); jednak zamiana na głoski spoza systemu języka polskiego (deformacje) wymaga natychmiastowej interwencji logopedycznej.

Zaburzenia wymowy u dzieci dwujęzycznych należy odróżnić od naleciałości fonetycznych pojawiających się na skutek zanurzenia w języku kraju, w którym dziecko funkcjonuje. W sytuacji gdy posługuje się ono przez większość czasu językiem innym niż polski - w kontaktach z rówieśnikami, w szkole, a czasem również w relacji z jednym z rodziców - nie należy oczekiwać, że będzie w sposób idealny, zgodny z najwyższymi normami poprawnościowymi wymawiało tzw. trudne głoski, charakterystyczne dla polskiego systemu fonetycznego, takie jak: $s z, \dot{z}, c z, d \dot{z}$ (Madelska 2010).

Terapię logopedyczną i korekcję wad wymowy u dzieci dwujęzycznych należy bezzwłocznie rozpocząć wówczas, gdy powodują one nieporozumienia lub odbiór mowy dziecka jest bardzo utrudniony. Pracę nad korekcją wad wymowy - w trosce o kulturę języka ojczystego - warto jednak rozpocząć również w przypadku, gdy nie stanowią one dużego problemu komunikacyjnego.

Zakres interwencji terapeutycznej powinien każdorazowo ocenić polski logopeda. Nierzadko po wstępnej diagnozie kieruje on dziecko do innych specjalistów (np. laryngolog, ortodonta, foniatra), aby usunąć pierwotną przyczynę trudności i móc rozpocząć terapię logopedyczną.

Sygmatyzm może być powodowany przez jeden bądź kilka czynników. W klasycznym podziale opracowanym przez Leona Kaczmarka wyróżnia się przyczyny mechaniczne, audiogenne, środowiskowe, a także uwarunkowane uszkodzeniami ośrodków i dróg nerwowych oraz sprzężone (Kaczmarek 1982, Sołtys-Chmielowicz 2008).

\section{Przyczyny mechaniczne:}

- nieprawidłowości w budowie języka, np. zbyt duży lub zbyt mały język, zbyt krótkie wędzidełko podjęzykowe;

- wady zgryzu: zgryz otwarty, przodozgryz, tyłozgryz, zgryz skrzyżowany; 
- anomalie zębowe: wychylenie górnych zębów przednich do przodu bądź do tyłu jamy ustnej, szpara między jedynkami (diastema), braki w uzębieniu;

- nieprawidłowa budowa podniebienia: zbyt mocno wysklepione podniebienie, rozszczepy podniebienia;

- wady anatomiczne utrudniające prawidłowe oddychanie: np. przerośnięte migdały, skrzywiona przegroda nosowa.

\section{Przyczyny audiogenne:}

- zaburzenia słuchu fonematycznego;

- głuchota lub niedosłuch, wybiórcze uszkodzenia słuchu;

- zaburzenia analizy i syntezy słuchowej.

\section{Przyczyny środowiskowe:}

- brak właściwej stymulacji językowej;

- wady wymowy występujące u rodziców.

Własna praktyka terapeutyczna oraz najnowsza literatura fachowa pozwalają stwierdzić, że wady wymowy mogą być również powodowane:

- przewlekłym (często bez objawów bólowych) zapaleniem ucha środkowego, powodującym długotrwałą deprywację słuchową (Czech, Malicka, Kott, Zakrzewska 2011);

- przetrwałym połykaniem niemowlęcym (Kawala, Babijczuk, Czekańska 2003);

- dyspraksją, której towarzyszą trudności w wykonywaniu celowych ruchów języka i warg (Obrębowski, Obrębowska 2013);

- zaburzeniami centralnego przetwarzania słuchowego (Kwaśniok, Ławecka 2016).

U polskich dzieci dwu- lub wielojęzycznych często pojawia się dodatkowa trudność związana ze słabym różnicowaniem spółgłosek ś, ź, ć, $d \dot{z}$ w opozycji do $s z, \dot{z}, c z, d \dot{z}$. Jej źródłem są najczęściej zaburzenia słuchu fonematycznego, a także odmienna świadomość fonologiczna i - spowodowany ekspozycją na języki obce - nierzadko wolniejszy rozwój słuchu fonematycznego (Madelska 2010).

Zarówno sygmatyzm, jak i inne wady wymowy (np. rotacyzm - nieprawidłowa realizacja głoski $r$ ), przekładają się na sposób artykulacji w obydwu językach (McLeod, Goldstein 2012).

W Wielkiej Brytanii podejście do korekcji wad wymowy jest nieco odmienne od tego, które obowiązuje w Polsce, inny jest również system, w ramach którego można uzyskać pomoc logopedy. Zarówno w primary school (szkoła podstawowa), jak i w secondary school (gimnazjum) nie można skorzystać z terapii prowadzonej przez speech and language therapist (logopeda). W ramach szkolnej opieki logopedycznej możliwe jest wyłącznie zdiagnozowanie (nie terapia) dziecka pod kątem wad wymowy 
i to jedynie na wyraźne życzenie rodziców. Z oczywistych powodów angielski logopeda nie zdiagnozuje wad wymowy charakterystycznych dla języka polskiego. Przyjmuje się, że u uczniów, u których zaburzenia artykulacyjne nie wpływają w znacznym stopniu na komunikację, nie ma powodu do interwencji. Długofalowa terapia wad wymowy - a tylko taka zapewnia osiągnięcie sukcesu oraz implementację nowych nawyków w obszarze mowy spontanicznej - w Wielkiej Brytanii zawsze pozostaje w gestii rodziców.

Kształtowanie słuchu fonematycznego $u$ małych dzieci jest jedną z metod pozwalających na zapobieżenie sygmatyzmowi (Sachajska 2004) oraz wsparcie właściwej terapii logopedycznej (Szpilman, Morawski, Lewandowska, Jerzak, Sosnowska-Wieczorek 2016). Rola nauczycieli szkół sobotnich jest $\mathrm{w}$ tym przypadku nieoceniona - ćwiczenia słuchu fonematycznego odgrywają bowiem niebagatelną rolę nie tylko w nauce poprawnej artykulacji (Włodarczyk, Szkiełkowska, Skarżyński, Piłka 2011), ale u starszych uczniów - również w opanowaniu umiejętności czytania i pisania (Gindrich 2001).

Słuch fonematyczny (słuch fonemowy, słuch fonologiczny, słuch mowny, percepcja słuchowa) to umiejętność rozróżniania najmniejszych elementów składowych wyrazów - fonemów (np. $a$ od o), a także odbiór cech prozodycznych mowy (Styczek 1977). Następstwem poprawnego różnicowania fonemów jest zdolność rozróżniania wyrazów, w tym również tych, które brzmią podobnie (np. murek - nurek).

Fonem to abstrakcyjna jednostka językowa oznaczająca zespół stałych i istotnych właściwości głoski, określanych mianem cech dystynktywnych głoski, a warunkowanych jej właściwościami artykulacyjnymi: miejscem artykulacji, stopniem zbliżenia narządów mowy, dźwięcznością (bądź jej brakiem) oraz ustnością/nosowością. Dzięki cechom dystynktywnym jesteśmy w stanie szczegółowo opisać każdą głoskę, a także - co istotne - w praktyce odróżnić w procesie komunikacyjnym poszczególne wyrazy.

W jaki sposób przebiega rozwój słuchu fonematycznego? Przyjmując klasyfikację Lewiny, możemy wyróżnić 5 etapów nierozerwalnie złączonych $\mathrm{z}$ rozwojem mowy (Kania 1982):

- przedfonematyczny, charakteryzujący się brakiem różnicowania dźwięków, brakiem mowy czynnej i jej rozumienia;

- etap rozróżniania fonemów najmniej podobnych powiązany z pojawieniem się mowy - jeszcze niepoprawnej i zniekształconej;

- początek rozróżniania subtelnych różnic między fonemami i pojawienie się świadomości poprawnej wymowy;

- doskonalenie różnicowania głosek i doskonalenie poprawnej wymowy;

- zakończenie rozwoju słuchu fonematycznego zwieńczone osiągnięciem pełnej biegłości w zakresie artykulacji. 
Przyjmuje się, że rozwój słuchu fonematycznego - z uwzględnieniem różnic indywidualnych, również u dzieci dwujęzycznych - powinien się zakończyć między 5. a 7. rokiem życia (Gruba 2012, Madelska 2010).

Zaburzenia słuchu fonematycznego manifestują się m.in. opóźnieniem w rozwoju i rozumieniu mowy, wadami wymowy, a także trudnościami w nabyciu umiejętności pisania i czytania (Gruba 2012), rzutując na całość komunikacji i finalnie obniżając szanse edukacyjne dziecka.

Diagnostyka zaburzeń słuchu fonematycznego powinna być przeprowadzona przez logopedę, niemniej ćwiczenia percepcji słuchowej mogą być z powodzeniem stosowane przez nauczycieli polskich szkół sobotnich, stanowiąc zarówno działania profilaktyczne, jak i realną pomoc dla dzieci z trudnościami w tym obszarze. Należy pamiętać, aby zajęcia prowadzone były zawsze $\mathrm{z}$ pomocą materiałów wizualnych (obrazki), a słownictwo dostosowane do rzeczywistości dzieci dwujęzycznych. Warto dołożyć również starań, aby dzieci chętnie angażowały się w zabawy, w czym pomocne może okazać się wplatanie w ćwiczenia elementów humorystycznych.

Ćwiczenia słuchu fonematycznego bazują na wytworzeniu stałych wzorców słuchowych (Styczek 1977), dlatego też ich skuteczność warunkowana jest wielokrotnym powtarzaniem.

Ćwiczenia opierające się na słuchu fizjologicznym i muzycznym:

- rozpoznawanie odgłosów darcia papieru, przelewanej wody, stukania długopisem o biurko (czynności wykonywane są tak, aby dziecko ich nie widziało);

- dziecko opowiada, jakie odgłosy słyszy na szkolnym korytarzu, za oknem;

- wskazywanie źródła dźwięku, np. odszukiwanie tykającego zegarka;

- dziecko ma zakryte oczy, stara się „iść za dźwiękiem”;

- różnicowanie wysokich i niskich dźwięków - kiedy dźwięki są wysokie, dziecko chodzi na palcach, kiedy niskie - z ugiętymi kolanami;

- nauka rozpoznawania dźwięków różnych instrumentów, np. fletu, dzwonków, tamburynu (czynności wykonywane są tak, aby dziecko ich nie widziało);

- powtarzanie przez dziecko rytmu wystukiwanego przez nauczyciela.

Ćwiczenia skupiające się na różnicowaniu głosek:

- porównywanie głosek rozpoczynających słowa (czy słowo foka zaczyna się od $f$ ?);

- porównywanie ostatnich głosek w słowie (czy słowo pies kończy się tak samo jako lis?);

- wyodrębnianie pierwszej, środkowej i końcowej głoski w słowie (jaką głoską zaczyna się słowo rak?);

- wyodrębnianie poszczególnych głosek w słowie w prawidłowej kolejności (jakie trzy głoski tworzą słowo mak?);

- liczenie głosek w słowie (ile jest głosek w słowie rok?); 
- $\quad$ synteza poszczególnych głosek w słowo (jakie to słowo $s-o-k$ ?);

- pomijanie głosek (teraz powiedz las bez l);

- odgadywanie, jakiej głoski brakuje (powiedz pas, a teraz as, jakiej głoski brakuje?);

- zastępowanie głosek (powiedz rak, a teraz powiedz $m$ zamiast $r$ ).

Ćwiczenia rymów:

- przygotowanie kilkunastu par obrazków (np. kozy - wozy, kura góra, nogi - rogi, żaba - ptak, ucho - usta), dziecko odkłada na bok te pary obrazków, które się rymują;

- przygotowanie kilkunastu obrazków w sekwencjach po trzy (np. góry - kangury - puszki, noga - ręka - stonoga), dziecko wybiera te dwa obrazki (spośród trzech), które się rymują;

- przygotowanie kilkunastu par obrazków (np. fale - szale, półki bułki), dziecko rysuje obrazek, który będzie się rymował z otrzymaną parą;

- uzupełnianie rymowanek o brakujące słowo, np. Lata mucha koło... (ucha), Smaczny dżem chętnie... (jem), Lody, lody dla... (ochłody).

Wyszukiwanie słów w słowie (praca na materiale obrazkowym):

- jakie nowe słowo powstanie, jeśli opuścimy ostatnią głoskę? (np. buty - but, góral - góra);

- jakie nowe słowo powstanie, jeśli opuścimy pierwszą głoskę? (np. ekran - kran, kość - ość);

- rebusy słowne.

\section{Bibliografia:}

Czech Dorota, Malicka Małgorzata, Kott Ewa, Zakrzewska Anna, 2011, Ocena występowania zaburzeń artykulacyjnych u dzieci z nawracajacymi infekcjami górnych dróg oddechowych, „Otolaryngologia”, nr 10 (3).

Gindrich Piotr, 2001, Znaczenie systemu językowego, świadomości fonologicznej oraz metajęzykowej w badaniach nad geneza dysleksji, „Audiofonologia”, nr 19.

Gruba Joanna, 2012, Ocena słuchu fonemowego u dzieci w wieku przedszkolnym, Katowice.

Kaczmarek Leon, 1981, Nasze dziecko uczy się mowy, Lublin.

Kania Józef Tadeusz, 1982, Szkice logopedyczne, Warszawa.

Kawala Beata, Babijczuk Tomasz, Czekańska Anna, 2003, Występowanie dysfunkcji, parafunkcji i wad narzadu żucia u dzieci w wieku przedszkolnym, „Dental and Medical Problems”, nr 40 (2).

Kwaśniok Ewa, Ławecka Magdalena, 2016, Stymulacja funkcji słuchowych w zaburzeniach centralnych procesów przetwarzania, „Forum Logopedyczne", nr 24 . 
Madelska Liliana, 2010, Bliźniacze słowa. Test przesiewowy do badania dojrzałości szkolnej w zakresie percepcji i wymowy dzieci wielojęzycznych, Lublin.

McLeod Sharynne, Goldstein Briad (red.), 2012, Multilingual Aspects of Speech Sound Disroders in Children. Multilingual Matters - Bristol, Buffalo, Toronto.

Obrębowski Andrzej, Obrębowska Zofia, 2013, Diagnostyka etiologiczna zaburzeń artykulacji, „Otolaryngologia”, nr 12 (2).

Polska Macierz Szkolna - strona internetowa, http://www.polskamacierz.org/ (dostęp: 3.08.2018)

Sachajska Elżbieta, 2004, Uczymy się poprawnej wymowy, Warszawa.

Sołtys-Chmielowicz Anna, 2008, Zaburzenia artykulacji. Teoria i praktyka, Kraków.

Stańczak Joanna, 2015, Dzieci w Polsce w 2014 roku, charakterystyka demograficzna, https://stat.gov.pl/files/gfx/portalinformacyjny/pl/ defaultaktualnosci/5468/20/1/1/dzieci w polsce w 2014 roku charakterystyka_demograficzna.pdf (dostęp: 3.08.2018)

Styczek Irena, 1977, Badanie i kształtowanie słuchu fonematycznego, Warszawa.

Szpilman Magdalena, Morawski Krzysztof, Lewandowska Iwona, Jerzak Katarzyna, Sosnowska-Wieczorek Iwona, 2016, Ocena słuchu fonemowego u dzieci jedno- i dwujęzycznych w wieku przedszkolnym, „Otolaryngologia”, nr 15 (3).

Włodarczyk Elżbieta, Szkiełkowska Agata, Skarżyński Henryk, Piłka Adam, 2011, Zaburzenia artykulacji u dzieci ze współistniejacymi zaburzeniami przetwarzania słuchowego - efekty terapii słuchowej, „Otolaryngologia Polska”, nr 65.

\section{O Autorce:}

Monika Plata - absolwentka filologii polskiej, dziennikarstwa oraz logopedii na Uniwersytecie Warszawskim, a także neurologopedii w Szkole Wyższej Przymierza Rodzin. Od 2014 pracuje w Londynie jako terapeutka mowy oraz terapeutka integracji sensorycznej z dziećmi dwujęzycznymi z zaburzeniami komunikacji. Jest asystentką w Zakładzie Nauk o Zdrowiu Polskiego Uniwersytetu na Obczyźnie w Londynie (PUNO). Jej zainteresowania koncentrują się na wspomaganiu komunikacji u dzieci ze spektrum autyzmu oraz u osób z apraksją. Prowadziła w PUNO liczne warsztaty i szkolenia dla nauczycieli szkół sobotnich dotyczące szeroko rozumianej logopedii. Pomysłodawczyni i kierownik Poradni Logopedycznej działającej przy PUNO. Prowadziła konsultacje logopedyczne w szkołach sobotnich w Londynie, a także w Poradni Rodzinnej działającej przy Stowarzyszeniu Polskich Psychologów w Londynie. Partner merytoryczny Fundacji Synapsis w ramach Programu Badabada. Współautorka książki Po polsku na Wyspach - a guide for parents of bilingual children (rozdział Mowa - okno na świat; Speech - a window to the world) - Londyn 2016, Nowy Jork 2017. 